\title{
PELESTARIAN LINGKUNGAN MELALUI PARTISIPASI PETANI DALAM PEMBENTUKAN RUANG PUBLIK DI DESA BULUTELLUE
}

\author{
Abdul Rahman ${ }^{1}$, Muhammad Syukur ${ }^{2}$, Rifal $^{3}$ \\ ${ }^{1}$ Program Studi Pendidikan Antropologi \\ ${ }^{2}$ Program Studi Pendidikan Sosiologi \\ ${ }^{3}$ Program Studi Pendidikan Sejarah \\ Fakultas Ilmu Sosial, Universitas Negeri Makassar \\ Kampus Gunungsari Baru, Jalan Andi Pangerang Pettarani, Makassar \\ Alamat e-mail: ${ }^{1}$ abdul.rahman8304@ unm.ac.id ${ }^{2}$ syukurmuhammad10@gmail.com \\ rifalmattirodeceng@unm.ac.id
}

\begin{abstract}
Abstrak
Penelitian ini bertujuan untuk menguraikan partisipasi masyarakat dalam melestarikan hutan dengan memanfaatkan ruang publik sebagai arena aktivitas di Desa Bulutellue, Kecamatan Bulupoddo, Kabupaten Sinjai, Provinsi Sulawesi Selatan. Metode yang digunakan dalam penelitian ini adalah dengan pendekatan kualitatif. Pengumpulan data dilakukan dengan cara pengamatan terlibat dan wawancara terhadap tokoh masyarakat, aparat pemerintah desa, dan tokoh adat. Hasil penelitian menunjukkan bahwa upaya untuk melestarikan lingkungan dilakukan secara mandiri oleh masyarakat melalui pembentukan opini melalui diskusi di gardu sebagai ruang publik, pembentukan kelompok kerja yang otonom, dan ritual upacara adat. Upaya tersebut terbukti efektif dalam menjaga kelestarian lingkungan berserta sumber daya di dalamnya, sehingga mereka optimis akan keberlanjutan lingkungan dan dapat diwariskan kepada generasi selanjutnya.
\end{abstract}

Kata Kunci: partisipasi masyarakat; ruang publik; kelestarian lingkungan;

\begin{abstract}
This study aims to describe community participation in conserving forests by utilizing public space as an arena of activity in the Village of Bulutellue, Bulupoddo District, Sinjai Regency, South Sulawesi Province. The method used in this research is a qualitative approach. Data collection was carried out by means of observations involved and interviews with community leaders, village government officials, and traditional leaders. The results showed that efforts to preserve the environment were carried out independently by the community through the formation of opinions through discussions in substations as public spaces, the formation of autonomous working groups, and traditional ceremonial rituals. These efforts have proven effective in preserving the environment and the resources in it, so they are optimistic about environmental sustainability and can be passed on to future generations.
\end{abstract}

Keywords: community participation; public space; environmental sustainability;

\section{PENDAHULUAN}

Pasca keruntuhan Uni Soviet sebagai pengusung utama sistem ekonomi sosialisme, posisi Amerika Serikat dan negara-negara di kawasan Eropa Barat semakin kuat dan gencar dalam menyebarkan pengaruh sistem ekonomi kapitalis ke negara-negara dunia ketiga. Kapitalisme telah memasuki babak perkembangan baru 
dan bertransformasi dengan melahirkan karakteristiknya yang baru (Amin, 1999). Kapitalisme tampil tidak lagi sebagai imperialisme atau penjajahan secara fisik terhadap negara-negara yang sedang berkembang, tetapi sistem ini bermetamorfosis sebagai pemberi bantuan dalam menggerakkan roda pembangunan di negara berkembang melalui investasi. Negara-negara yang berada pada barisan negara kaya (maju), misalnya Amerika Serikat, Kanada, Inggris, Perancis, dan Jepang terus mengembangkan korporasi mereka, menggenjot ekspornya, dan berekspansi ke luar negeri.

Keberhasilan ekonomi yang dicapai oleh negara-negara maju tidak dapat dipisahkan dari revolusi industri yang mereka galakkan sejak 1870-an. Industriindustri yang mereka kembangkan hingga saat ini tentunya memerlukan bahan baku. Untuk memperoleh bahan baku tersebut, mereka senantiasa melakukan pergerakan ke negara-negara di luar kawasan Amerika dan Eropa, dalam hal ini negara-negara yang sedang bekembang di kawasan Asia dan Afrika . Kemampuan negara-negara maju dalam meyakinkan negara-negara berkembang untuk mensuplay bahan baku kepada industri mereka, semakin memperkokoh posisi kemajuan dan kestabilan ekonomi mereka (Maemunah \& Hakim, 2018).

Situasi yang terjadi di negara-negara maju berbanding terbalik dengan situasi di negara-negara yang masih berkembang, termasuk Indonesia. Indonesia sedang berusaha untuk meningkatkan kesejahteraan masyarakatnya dengan menerapkan berbagai kebijakan dalam bidang ekonomi. Sejak zaman Orde Baru hingga saat ini, Indonesia cenderung menjadi negara yang mengeksploitasi sumber daya alamnya untuk memenuhi kepentingan ekspor ke negara-negara industri maju untuk mewujudkan pertumbuhan ekonomi. Akibatnya, lingkungan mengalami kerusakan dan memunculkan permasalahan sosial berupa kemiskinan terhadap masyarakat yang bermukim di sekitar lingkungan itu.

Kerusakan lingkungan telah menjadi bahan perbincangan pada berbagai kalangan di negara ini. Isu ini banyak diperbincangkan oleh elite di lembagalembaga pemerintahan, kalangan akademisi dan mahasiswa dari lingkungan perguruan tinggi, dan para penggiat lingkungan yang tergabung dalam berbagai lembaga swadaya masyarakat. Mereka melaksanakan berbagai seminar dan tampil 
sebagai orator yang handal, melakukan kritikan terhadap berbagai pihak, termasuk menghujat pemerintah yang dinilai tidak mampu mengatasi permasalahan lingkungan itu. Akan tetapi, ini hanya sebatas wacana yang tidak akan bermanfaat ketika tidak dibarengi dengan aksi.

Kerusakan lingkungan jika tidak menjadi perhatian dan penanganan yang serius melalui aksi nyata, maka kedaulatan negara akan sangat mudah untuk diintervensi oleh pihak luar, karena ketiadaan pemahaman akan arti pentingnya lingkungan bagi kelangsungan hidup bangsa. Kerusakan lingkungan yang terjadi di Indonesia saat ini merupakan ancaman serius bagi keberlangsungan peradaban. Kerusakan lingkungan saat ini telah melanda hampir berbagai sektor kehidupan utama, antara lain: kerusakan tanah, krisis air, dan kerusakan hutan. Padahal tanah, air, dan hutan merupakan unsur penting dalam keberlangsungan hidup manusia, terutama pada masyarakat petani yang bermukim di wilayah perdesaan.

Ketergantungan kehidupan terhadap lingkungan telah mendorong petani untuk bertindak dalam melakukan pelestarian lingkungan. Beberapa studi yang terkait dengan gerakan pelestarian lingkungan antara lain dilakukan oleh Sudalmi dan Hardiatmi. Dalam studinya, mereka menemukan bahwa warga di Desa Wonorejo, Kabupaten Karanganyar melakukan gerakan pelestarian lingkungan dengan memanfaatkan pekarangan (Sudalmi \& Hardiatmi, 2018). Sementara itu studi yang dilakukan oleh Putra dkk menemukan bahwa dalam rangka menjaga kelestarian sumber daya air, masyarakat aceh memanfaatkan lembaga adat lokal kejreun blang (Putra \& Hariadi, 2016). Hal yang sama dilakukan oleh Ruhimat. Dalam studinya ditemukan bahwa petani Kecamatan Lumbung, Kabupaten Ciamis menjaga kelestarian lingkungan dengan menggunakan sistem agroforestry (Ruhimat, 2015). Artikel ini juga akan membahas tentang pelestarian lingkungan yang dilakukan oleh masyarakat petani di Desa Bulutellue, Kabupaten Sinjai, Provinsi Sulawesi Selatan dengan membentuk dan memanfaatkan ruang publik. Artikel ini berupaya untuk mengelaborasi pemikiran Jurgen Habermas yang menyatakan bahwa masyarakat dalam menghadapi fenomena di sekitarnya akan memanfaatkan ruang publik dalam membangun kesadaran, pengetahuan, dan kepentingan (Noor, 2016) yang berujung pada aksi atau tindakan secara kolektif. 


\section{METODE}

Penelitian ini menggunakan pendekatan secara kualitatif dalam proses pengumpulan data. Menurut Jasmi, data yang dikumpulkan melalui pendekatan kualitatif merupakan uraian secara rinci melalui bentuk deskriptif naratif yang diperoleh langsung dari lokasi penelitian (Yew, Ramlan, \& Ahmad, 2019). Agar tujuan penelitian dapat dicapai dan memiliki kesesuaian dengan metode yang digunakan, maka pengumpulan data dilakukan dengan cara pengamatan terlibat (Bachtiar, 1991). Peneliti bergabung dengan masyarakat untuk mengamati kegiatan keseharian mereka. Selain itu, dilaksanakan pula wawancara untuk memperoleh informasi dan pemahaman yang holistik terkait dengan pengalaman, motif, dan perasaan yang dialami oleh masyarakat.

Model wawancara yang digunakan adalah wawancara bebas dan santai, ditambah dengan mengikuti forum-forum diskusi lepas yang terjadi di lingkungan rumah tangga masyarakat petani. Wawancara berpedoman pada pokok-pokok pertanyaan yang telah disiapkan, dan memberikan kesempatan kepada masyarakat untuk berbicara secara bebas. Dari pembicaraan itu, kemudian peneliti mengambil data-data yang terkait dengan fokus penelitian. Jika ada informasi yang meragukan, maka informasi itu disampaikan kepada pihak lain untuk memastikan kebenarannya. Berdasarkan pengalaman di lapangan, semua informasi yang disampaikan oleh setiap individu memiliki kesamaan satu sama lain sehingga layak untuk dijadikan data dalam menyusun artikel ini.

\section{HASIL DAN PEMBAHASAN}

Petani di Desa Bulutellue memahami bahwa manusia mempunyai keterkaitan dengan alam, dan perilaku manusia terhadap alam mempunyai dampak terhadap kehidupan manusia. Parsudi Suparlan menyatakan bahwa keterkaitan antara manusia dengan alam sekitar dan lingkungan fisik bukan hanya seksdar sebagai hubungan ketergantungan manusia terhadap alam sekitar, tetapi juga terwujud sebagai hubungan di mana manusia memengaruhi dan memanfaatkan alam sekitar (Febrianto, 2016). Kemampuan petani yang didukung potensi 
kemampuan berpikir dan bernalar dalam memanfaatkan alam sekitar, membuat mereka mampu memperoleh kesejahteraan, kemakmuran dan mempertahankan keberlangsungan hidup (Surtani, 2016). Tindakan petani dalam memanfaatkan alam sekitar untuk keberlangsungan hidup merupakan tindakan rasional. Hal tersebut diperkuat oleh Samuel Popkin bahwa petani merupakan manusia-manusia dalam bertindak sangat rasional, kreatif dan berorientasi pada kekayaan (Popkin, 1986).

Kehidupan petani di Desa Bulutellue sangat bergantung pada lingkungan fisik yaitu sawah, kebun, hutan, dan sungai. Dalam pemanfaatan dan pengolahan lingkungan fisik untuk keperluan mencari nafkah, para petani sangat memperhatikan aspek keberlanjutan. Bagi mereka, lingkungan fisik harus tetap terjaga untuk kepentingan generasi yang akan datang. Lingkungan fisik tidak boleh dieksploitasi secara berlebihan demi keuntungan ekonomi, sebab lingkungan fisik hanya dimanfaatkan untuk pemenuhan kebutuhan sehari-hari, sedangkan untuk kepentingan komersil misalnya uang tabungan untuk keperluan di luar kebutuhan rumah tangga sehari-hari diperoleh dengan cara memelihara ternak. Perilaku petani tersebut senada dengan konsep keberlanjutan ekologi yaitu usaha untuk mengelola dan memanfaatkan sumber daya alam secara bijaksana dengan tidak memunculkan dampak negatif terhadap lingkungan dan berlaku adil untuk kepentingan generasi mendatang (Keraf, 2010).

Pelestarian lingkungan, selain menjadi tanggung jawab masyarakat setempat, juga diperlukan kehadiran negara. Tanggung jawab negara untuk menjaga kelestarian lingkungan dilakukan dengan cara membentuk penyuluh pertanian dan polisi kehutanan. Khusus di wilayah Desa Bulutellue, hanya penyuluh pertanian yang aktif melakukan sosialisasi kepada masyarakat, sedangkan polisi kehutanan tidak ada yang bertugas di desa ini karena tidak ada kawasan hutan lindung. Semua hutan yang ada di Desa Bulutellue dikelola, dimanfaatkan, dan dibawah penguasaan individu yang dibuktikan dengan sertifikat dan surat pajak bumi dan bangunan. Masyarakat petani di Desa Bulutellue menyadari bahwa kelestarian lingkungan tidak dapat diserahkan dan dipercayakan kepada aparat negara, sebab aparat tersebut bukan merupakan penduduk asli di Desa Bulutellue sehingga tidak ada sama sekali ikatan emosional dengan masyarakat dan 
lingkungan setempat. Mereka bekerja hanya karena semata-mata melaksanakan perintah dari negara, bukan karena dorongan kesadaran yang memang bertujuan untuk keberlanjutan dan kelestarian lingkungan.

Rendahnya tingkat kepercayaan dan harapan masyarakat petani kepada lembaga pemerintah dalam menjaga kelestarian lingkungan menjadi faktor utama bagi mereka untuk bertindak sendiri. Tindakan tersebut bertolak dari adanya melek ekologi (ecoliteracy) di kalangan masyarakat petani. Bagi Fritjof Capra ecoliteracy merupakan penggambaran manusia yang sudah mencapai tingkat kesadaran tinggi tentang pentingnya lingkungan hidup yang dibuktikan dengan partisipasi aktif mereka dalam menjaga dan merawat bumi, ekosistem, dan alam sebagai tempat bermukim dan berkembangnya kehidupan (Keraf, 2014). Basis utama ecoliteracy yang dimiliki oleh masyarakat petani ialah kearifan lokal. Kearifan lokal merupakan basis struktur dari masyarakat untuk melangsungkan kehidupan selaras dengan situasi alam sekitar, berdasarkan pada kebutuhan, dan kepercayaan yang telah berakar dan sulit untuk dihilangkan (Sufia, Sumarmi, \& Amirudin, 2016). Lebih lanjut Amri Fauzul menerangkan bahwa kearifan lokal merupakan pengetahuan, pemahaman dan kebiasaan yang dijadikan sebagai panduan kehidupan manusia untuk beraktivitas sebagai anggota masyarakat yang berhubungan dengan komunitas ekologis (Norsidi, 2019). Masyarakat petani memiliki keyakinan bahwa jika lingkungan diabaikan kelestariannya dan berujung pada kerusakan maka Fammaneng Tana (malaikat penjaga lingkungan) akan murka dan mengadu kepada Fuang Alla Taala (Tuhan) agar masyarakat yang bermukim dan mencari nafkah di sekitar lingkungan tersebut tidak lagi diberi keberkahan dan kesejahteraan hidup. Sebagai umat yang beragama mereka pun berpandangan bahwa sepanjang perjalanan sejarah umat manusia, tradisi keagamaan Islam telah memberikan dukungan dan inspirasi pada setiap saat dalam menghadapi perkembangan dan tantangan zaman yang semakin kompleks. Tuhan telah memberikan perintah kepada manusia agar senantiasa bertebaran di muka bumi dalam mencari nafkah dan memperoleh keuntungan setelah menunaikan kewajibannya. Akan tetapi pada sisi lain, Tuhan juga memberikan peringaan bahwa 
kerusakan yang terjadi pada alam semesta, baik di darat maupun di lautan tidak terlepas dari ulah manusia itu sendiri.

Salah satu usaha yang paling efektif dalam menjaga kelestarian lingkungan di Desa Bulutellue ialah dengan cara membentuk dan memanfatkan ruang publik. Jurgen Habermas menegaskan bahwa kehadiran ruang publik memberikan kesempatan yang luas kepada masyarakat untuk menyampaikan gagasan, kepentingan, kebutuhan dan sekaligus sebagai arena bagi masyarakat yang bebas dari intervensi pemerintah untuk melakukan komunikasi satu sama lain dalam membahas berbagai macam problematika kehidupan. Ruang publik bukan hanya mewujud dalam bentuk fisik, tetapi hadir pula dalam bentuk kelompok informal (Hardiman \& Sitorus, 2009). Kehadiran ruang publik bukan hanya didesain untuk menampung memori kolektif, tetapi dirancang pula untuk dimanfaatkan masyarakat untuk merajut memori kolektif menuju aksi kolektif (Kusno, Kurnia, \& Budiman, 2009).

Pembentukan ruang publik dalam usaha pelestarian lingkungan merupakan forum komunikasi bagi masyarakat petani dalam menyampaikan berbagai ide dan tindakan yang hendak dilakukan. Gejala ini dipertegas oleh Jurgen Habermas bahwa ruang publik memiliki fungsi penting dalam demokratisasi. Ruang publik merupakan arena demokrasi bagi masyarakat untuk berdiskusi dalam menyampaikan keluh kesah, opini, kepentingan, keinginan, dan kebutuhan(Hardiman, 2010). Dipahami bahwa sektor perekonomian Desa Bulutellue didominasi oleh kegiatan pertanian yang sangat bertumpu pada lingkungan sekitar, dalam hal ini lahan sawah, hutan, dan sungai. Kegiatan pertanian menuntut akan pentingnya harmonisasi dengan lingkungan maupun dengan sesama manusia atas dasar rasa kekeluargaan dan perkawanan. Kondisi tersebut diupayakan tetap bertahan agar mudah mencapai kebutuhan-kebutuhan hidup mereka dan mempertahankan sistem keamanan kampung.

Pelestarian lingkungan hidup menjadi hal yang sangat fundamental dalam kerangka pencapaian kebutuhan ekonomi dan penciptaan interaksi sosial yang harmonis antar masyarakat. Lingkungan memiliki nilai strategis dari sisi ekonomi, hubungan-hubungan sosial, maupun arena kebudayaan. Menjadi harapan setiap 
masyarakat petani bahwa segenap potensi lingkungan harus dikelola dengan tetap memperhatikan aspek keberlanjutan untuk menopang kebutuhan ekonomi masyarakat secara turun temurun. Agar lingkungan tetap terpelihara dan terus menjadi sumber penghidupan, maka masyarakat petani melakukan berbagai upaya nyata, antara lain: pertama, pemanfaatan gardu. Abidin Kusno menjelaskan bahwa gardu merupakan bagian dari ruang publik dalam bentuk fisik yang merepresentasikan kehadiran negara di tengah masyarakat, namun pada sisi lain gardu juga merupakan bentuk perlawanan terhadap kebijakan negara yang menimbulkan keresahan di tengah masyarakat (Kusno, Utama, \& Nazir, 2007). Gardu sebagai ruang publik didefenisikan sebagai arena atau lahan umum, di mana masyarakat dapat melaksanakan aktivitas publik fungsional maupun kegiatan sampingan lainnya yang dapat mempererat hubungan suatu komunitas, baik melalui kegiatan sehari-hari maupun kegiatan berkala (Giri, 2016).

Pemenuhan akan kebutuhan terhadap ruang bagi masyarakat petani dilakukan dengan cara mendirikan gardu di tepi jalan dan berhampiran dengan lingkungan pemukiman. Gardu dimanfaatkan sebagai tempat melepas kepenatan dikala malam telah tiba. Setelah melaksanakan Shalat Isya dan bersantap malam bersama keluarga, para kaum lelaki mulai berdatangan di gardu. Berbagai kegiatan yang mereka lakukan, antara lain main kartu, menikmati tayangan televisi, dan saling mengobrol satu sama lain. Obrolan biasanya mengarah pada aktivitas keseharian mereka sebagai petani. Dari gardu inilah juga para petani membahas mengenai rencana yang akan dilakukan untuk mengantisipasi kebakaran hutan jika musim kemarau telah tiba, atau rencana perbaikan daerah aliran sungai maupun saluran air irigasi untuk menyambut musim hujan sebagai pertanda awal mengolah lahan sawah. Fenomena yang terjadi di lapangan sesuai dengan konsepsi Jurgen Habermas bahwa ruang publik bukan hanya sebatas ruang fisik yang dikelola oleh sebuah organisasi atau institusi legal, tetapi arena bagi masyarakat untuk melakukan komunikasi satu sama lain. Ruang publik harus terbebas dari kepentingan pemerintah atau pemilik modal sehingga aspek keterbukaan dan transparansi dapat terwujud sesuai dengan kepentingan masyarakat. Ruang publik merupakan arena bagi masyarakat untuk mewujudkan solidaritas dan aksi kolektif 
dalam rangka membendung kepentingan elite politik maupun kepentingan para pemilik modal (Hardiman, 2010).

Obrolan yang berlangsung di gardu menghantarkan masyarakat petani berpartisipasi aktif dalam upaya pengelolaan dan pelestarian lingkungan. Partisipasi masyarakat petani dalam setiap tindakan dan pengambilan keputusan secara kolektif dalam tata kelola lingkungan akan meningkatkan kebersamaan dan solidaritas di tingkat perdesaan. Berdasar pada pemikiran Jurgen Habermas bahwa kesatuan dan solidaritas sosial masyarakat di era moderen, selain memanfaatkan doktrin agama atau kearifan lokal, perlu pula meningkatkan proses komunikasi sosial sebagai upaya menciptakan harmoni di lingkungan masyarakat. Untuk itu, diperlukan partisipasi warga masyarakat secara maksimal dalam menentukan arah pembangunan di wilayahnya (Nuris, 2016).

Sebagian gardu di wilayah Desa Bulutellue dilengkapi dengan televisi yang disediakan oleh para pengusaha atau aparat desa sebagai bentuk penghargaan terhadap masyarakat yang aktif dalam menjaga keamanan kampung. Melalui siaran televisi itu, para petani dapat memperoleh informasi dari berbagai wilayah yang terkemas dalam siaran berita maupun dalam bentuk iklan layanan masyarakat. Hal ini menunjukkan bahwa media massa memiliki peran yang cukup efektif dalam menginformasikan mengenai pentingnya kesadaran masyarakat dalam menjaga kelestarian lingkungan.

Kehadiran gardu telah menjadi arena bagi masyarakat petani untuk dimanfaatkan dalam berdiskusi mengenai kehidupan mereka di tengah iklim demokrasi yang semakin kondusif pasca pemerintahan Orde Baru. Gardu merupakan arena publik yang bebas dari intervensi penguasa atau kelompok elite, sehingga betul-betul menjadi arena murni yang diisi oleh kepentingan masyarakat. Gardu bukan hanya dipandang sebagai ruang fisik, tetapi merupakan arena produksi wacana melalui interaksi dan perbincangan. Gardu sebagai arena yang bebas dominasi menyebabkan para petani sebagai peserta obrolan memiliki kebebasan untuk menyampaikan gagasan ataupun kritikan yang disampaikan dengan suasana yang penuh kekeluargaan sehingga kesalahpahaman dapat dihindari. 
Upaya yang kedua dalam melestarikan lingkungan ialah dengan membentuk perkumpulan. Kebutuhan terhadap ruang publik bagi masyarakat petani di Desa Bulutellue sebenarnya telah terwujud dan terlembaga, karena dalam perspektif solidaritas, masyarakat di desa ini telah memiliki wadah dalam berbagai model sebagai sebuah sistem sosial yang terbentuk atas prinsip kekeluargaan yang dilandasi semangat kegotong royongan. Gagasan bahwa petani menjadi aktor utama dalam proses pelestarian lingkungan mendorong mereka untuk memiliki ikatan internal, dan merealisasikannya dalam bentuk perkumpulan. Para petani membentuk perkumpulan sebagai wadah kebersamaan dalam melakukan aktivitas yang bertujuan untuk pemeliharaan lingkungan. Perkumpulan tersebut dalam Bahasa Bugis dikenal dengan istilah malleleng. Perkumpulan ini merupakan kelompok kerja yang rata-rata terdiri atas 15 orang yang anggotanya didasarkan pada ikatan kekeluargaa, hubungan pertetanggaan, dan kedekatan lahan.

Sistem kerja dalam kelompok malleleng itu dilakukan secara bergilir. Masing-masing anggota kelompok memiliki giliran untuk mendapatkan bantuan kerja dalam pengolahan lahan sawah atau kebun. Setelah semua anggota kelompok telah mendapatkan giliran, maka kegiatan selanjutnya ialah bekerja bersama membersihkan hutan atau daerah aliran sungai yang berdekatan dengan lahan mereka. Kerja bersama dalam memelihara hutan dan daerah aliran sungai merupakan suatu tanggung jawab sosial karena mereka memiliki ketergantungan ekonomi terhadap hutan dan sungai.

Meskipun hutan telah dimiliki secara individu, tetapi segala sumber daya yang terdapat di dalamnya boleh diambil oleh siapa pun yang memerlukan, kecuali menebang pohon selain oleh pemilik kawasan hutan itu. Kegiatan mengambil hasilhasil hutan dan memanfaatkan lahan hutan merupakan bagian yang tidak terpisahkan dari perekonomian masyarakat di Desa Bulutellue. Hasil hutan menjadi katup pengaman penting guna mengatasi musim paceklik. Masyarakat di desa ini memiliki kebiasaan mengumpulkan hasil hutan selain kayu. Pengambilan hasil hutan mengikuti siklus musim hujan dan kemarau sehingga tidak dapat dilakukan setiap saat. Beberapa jenis hasil hutan hanya diambil atau ditemukan pada saat musim hujan tiba. Ketika musim hujan turun pertama kali, beberapa jenis tumbuhan 
mulai muncul yang dapat diamanfaatkan untuk kebutuhan komsumsi sayuran misalnya lempuyang, rebung, dan jamur kayu.

Bagi masyarakat petani di Desa Bulutellue, sumber daya hutan berupa kayu merupakan salah satu kebutuhan yang sangat penting. Kayu merupakan bahan utama untuk pembangunan rumah. Selain itu kayu juga dimanfaatkan untuk pembuatan alat-alat pertanian dan bahan bakar untuk kepentingan rumah tangga. Tingginya kebutuhan masyarakat terhadap kayu menjadi potensi besar akan munculnya kerusakan hutan. Untuk mengantisipasi hal tersebut maka ada beberapa tindakan yang dilakukan secara bersama oleh kelompok kerja malleleng itu antara lain:

1. Reboisasi. Jika musim hujan telah tiba, maka para petani secara bersama melakukan penanaman kembali. Penamaman tersebut dilakukan dengan cara stek atau memindahkan bibit tanaman pohon ke area yang sudah jarang.

2. Menerapkan sistem tebang pilih. Kebiasaan masyarakat dalam menebang pohon dilakukan dengan memilih pohon yang sudah tua dan memiliki diameter minimal $30 \mathrm{~cm}$.

3. Menerapkan sistem tebang-tanam. Pohon yang telah ditebang, diganti dengan menanam kembali atau memelihara bekas tebangan tersebut agar dapat muncul tunas yang baru.

4. Melakukan penebangan secara konservatif, yaitu melakukan penebangan pohon yang sudah tidak produktif atau pohon yang sudah mati akibat musim kemarau.

5. Menerapkan sistem tebang butuh, yaitu penebangan pohon hanya dilakukan ketika ada kebutuhan yang sangat mendesak untuk segera dipenuhi. Pada kondisi ini, keberadaan hutan lebih bersifat sebagai tabungan bagi petani. Petani menebang pohon untuk dijual kepada para pengusaha kayu untuk memenuhi kebutuhan mendesak misalnya biaya pendidikan anak, dan biaya untuk pesta keluarga. Kebutuhan mendesak yang lain ialah ketika kegiatan pembangunan sarana ibadah terkendala oleh ketersediaan kayu, maka petani secara sukarela menebang pohon untuk mengatasi kendala tersebut. 
Kehadiran kelompok kerja malleleng yang berbasis semangat kegotongroyongan atau kerjasama merupakan perwujudan masyarakat tanpa sekat. Jacques Ranciere memandang masyarakat tanpa sekat sebagai sebuah kualitas tatanan yang mengisyaratkan tingginya penghargaan terhadap etika kesetaraan. Pemahaman dan kesadaran akan pentingnya etika kesetaraan akan membuat individu percaya terhadap kemampuan intelegensinya sama dengan orang di sekitarnya, dan membangkitkan semangat belajar sehingga dapat menyadari segala tindakan yang dilakukan beserta konsekuensi yang akan ditimbulkan (Hambali, 2017). Gotong royong bagi masyarakat petani tidak hanya dimaknai sebagai kegiatan kerja bersama, tetapi sudah dihayati sebagai etika hidup dalam tata kehidupan bermasyarakat. Gotong royong merupakan penguatan identitas kebersamaan sehingga posisi mereka menjadi kuat dalam kehidupan bermasyarakat.

Aspek ketiga dalam upaya pelestarian lingkungan ialah pelaksanaan ritual atau kenduri. Ritual merupakan arena untuk mengingatkan manusia berkaitan dengan keberadaannya serta hubungan denga alam sekitar. Lingkungan memiliki peranan penting bagi keberlangsungan hidupan manusia. Lingkungan dapat mengalami perubahan fungsi karena berbagai faktor, salah satunya karena adanya perkembangan ilmu pengetahuan dan teknologi. Dampak permasalahan lingkungan dapat dirasakan oleh seluruh makhluk hidup dengan kemunculan fenomena alam yang menunjukkan ketidakwajarannya. Masalah lingkungan hidup memiliki keterkaitan erat dengan kearifan lokal. Hal ini dapat diketahui bahwa kehadiran kearifan lokal justru lebih dahulu memiliki peran dalam menjaga kelestarian lingkungan sebelum kemunculan aksi-aksi peduli lingkungan di berbagai wilayah. Bahkan dalam hal tertentu kearifan lokal lebih memiliki peran strategis dalam menjaga ekosistem dibandingkan dengan hukum yang telah ditetapkan oleh pemerintah dalam mengatur pola kehidupan dan tingkah laku masyarakat. Kehadiran mitos, ritual, dan pesan-pesan leluhur yang berkaitan erat dengan alam mampu mengatur masyarakat sedemikian rupa dalam hubungannya dengan lingkungan sekitar (Wibowo, Wasino, \& Setyowati, 2012). Ritual merupakan salah satu perwujudan budaya yang berkaitan erat dengan kehidupan manusia dan lokasi 
khusus dalam suatu permukiman. Menurut Douglas dalam Sasongko, suatu ritual khusus dapat dilihat dari dua sisi, yaitu sebagai aktivitas bagi manusia dalam mengidentifikasi zona untuk membersihkan diri (mensucikan diri) dan keteraturan, sementara di luar itu adalah polusi, ketidakpastian dan kekacauan, dan secara ritual menjauhkan diri secara fisik dari gangguan yang dapat membahayakan. Selanjutnya berbagai acara ritual ini berkaitan secara erat dengan batas (ruang) arsitektural. Secara fundamental, ritual dilaksanakan dengan memanfaatkan media kekuasaaan sebagai upaya untuk menjaga keharmonisan dalam kehidupan bermasyarakat demi mewujudkan tatanan kehidupan yang berkualitas (Arimbawa \& Santhyasa, 2010).

Salah satu ritual yang terkait dengan pelestarian lingkungan di Desa Bulutellue ialah mabbissa lompo yang secara harfiah berarti membersihkan kampung. Ritual ini dilaksanakan atas inisiatif masyarakat di bawah pimpinan seorang sanro (dukun kampung). Ritual ini dilaksanakan sebagai ungkapan rasa syukur atas selesainya para petani melaksanakan kegiatan bersawah yang ditandai dengan rampungnya penanaman bibit padi. Para petani dari berbagai kelompok umur dan jenis kelamin berkumpul pada waktu pagi di ruang terbuka yang ada di sekitar areal persawahan, selanjutnya bergerak bersama untuk bekerja membersihkan daerah aliran sungai, membersihkan saluran irigasi yang masuk ke areal persawahan dan menebas semak belukar dan rerumputan yang dapat menghambat aliran air.

Setelah diadakan pembersihan sampai pukul 10.00, para petani kembali berkumpul di tempat terbuka untuk melepas lelah sembari mengikuti pembacaan doa yang akan dipimpin oleh dukun kampung. Setelah pelaksanaan doa, rangkaian ritual dilanjutkan dengan penyampaian pesan-pesan dari Kepala Desa dan petugas penyuluh pertanian. Kepala Desa biasanya hanya menyampaikan pesan-pesan yang terkait dengan pentingnya kebersamaan masyarakat untuk menjaga keamanan desa. Sementara penyuluh pertanian menyampaikan tentang tata cara perawatan tanaman padi, proses pemupukan, pemberantasan hama yang ramah lingkungan dengan cara menghindari penggunaan pestisida. Setelah itu, ritual mabbissa lompo diakhiri dengan menikmati panganan yang telah dipersiapkan oleh masing-masing keluarga petani. 
Ritual mabbissa lompo yang dilaksanakan di ruang terbuka menciptakan suasana masyarakat tanpa sekat. Masyarakat menjadikan ritual tersebut sebagai arena untuk melakukan komunikasi satu sama lain. Masyarakat memiliki kebebasan untuk menyampaikan segala pemikirannya tanpa beban karena kondisi sosio kultural yang homogen terutama dalam hal sistem religi, sistem pengetahuan, masyarakat yang egaliter dan kondisi iklim perdesaan yang sejuk. Selain itu, dalam fungsinya sebagai media untuk menciptakan harmoni sosial, ritual mabbissa lompo dilakukan dengan kesepakatan dan keyakinan bersama sebagai penolak bencana, memperoleh kesuburan pertanian, dan ucapan rasa syukur kepada Tuhan.

Aksi pelestarian lingkungan yang dilakukan oleh masyarakat petani di Desa Bulutellue sesuai dengan paradigma ekosentrisme yang digagas oleh Arne Naess bahwa ketergantungan pada pemanfaatan ilmu pengetahuan dan teknologi bukan merupakan solusi yang tepat dalam melaksanakan kegiatan praktis dan teknis dalam rangka melestarikan lingkungan. Krisis lingkungan yang terjadi pada saat ini hanya bisa diatasi dengan melakukan perubahan secara mendasar dan cepat mengenai pemikiran dan tingkah laku manusia terhadap lingkungan alam. Hal yang dibutuhkan saat ini ialah merubah gaya hidup dan tingkah laku yang bukan hanya ditujukan secara personal, akan tetapi harus menjadi semacam aksi kolektif budaya masyarakat secara luas (Suyatman, 2018). Hal tersebut diperkuat oleh Maridi bahwa permasalahan lingkungan hidup dapat diatasi bukan hanya dengan mengandalkan pengetahuan ilmiah yang berbasis pada kemajuan sains dan teknologi, tetapi perlu pula memanfaatkan pengetahuan yang berbasis pada agama, religi, kearifan lokal dan etika (Maridi, 2015).

\section{SIMPULAN}

Masyarakat petani di Desa Bulutellue sangat aktif dalam melaksanakan tindakan pelestarian lingkungan. Hal tersebut berangkat dari kesadaran bahwa lingkungan yang ada saat ini bukan hanya untuk kepentingan mereka, tetapi akan diwariskan kepada generasi yang akan datang. Upaya pelestarian lingkungan dilakukan secara mandiri, tanpa berharap terlalu banyak kepada pihak pemerintah. Upaya masyarakat dalam melestarikan lingkungan tidak didasarkan pada 
pengetahuan ilmiah yang berbasis pada kemajuan sains dan teknologi, tetapi lebih mengandalkan pengetahuan lokal yang berbasis pada agama, etika dan moral.

\section{DAFTAR PUSTAKA}

Amin, S. (1999). Capitalism, imperialism, globalization. In The political economy of imperialism (pp. 157-168). Springer.

Arimbawa, W., \& Santhyasa, I. K. G. (2010). Perpektif Ruang Sebagai Entitas Budaya Lokal Orientasi Simbolik Ruang Masyarakat Tradisional Desa Adat Penglipuran, Bangli-Bali. Local Wisdom: Jurnal Ilmiah Kajian Kearifan Lokal, 2(4), 1-9.

Bachtiar, H. . (1991). Pengamatan Sebagai Suatu Penelitian. In Koentjaraningrat (Ed.), Metode-Metode Penelitian Masyarakat. Jakarta: Gramedia.

Febrianto, A. (2016). Antropologi Ekologi: Suatu Pengantar. Jakarta: Kencana.

Giri, A. A. G. M. (2016). Pelestarian Potensi Ruang Publik Sebagai Elemen Penting Dalam Pembangunan Desa Pakraman Kendran Sebagai Desa Wisata. Ruang: Jurnal Lingkungan Binaan (SPACE: Journal of the Built Environment), 3(3).

Hambali, A. (2017). Kesetaraan Radikal: Analisis Pemikiran Pendidikan Jacques Ranciere. Indonesian Journal of Sociology and Education Policy, 2(2), 1-25.

Hardiman, F. B. (2010). Ruang Publik. Yogyakarta: Kanisius.

Hardiman, F. B., \& Sitorus, F. K. (2009). Menuju masyarakat komunikatif: ilmu, masyarakat, politik, \& postmodernisme menurut Jurgen Habermas. Kanisius.

Keraf, A. S. (2010). Etika lingkungan hidup. Penerbit Buku Kompas.

Keraf, A. S. (2014). Filsafat Lingkungan Hidup, Alam Sebagai Sebuah Sistem Kehidupan. Yogyakarta: Kanisius.

Kusno, A., Kurnia, L., \& Budiman, M. (2009). Ruang publik, identitas dan memori kolektif: Jakarta pasca-Suharto. Ombak.

Kusno, A., Utama, C., \& Nazir, M. (2007). Penjaga memori: gardu di perkotaan Jawa. Ombak.

Maemunah, S., \& Hakim, M. L. (2018). Perubahan Iklim Dan Adaptasi Kapitalisme. Jurnal Legislasi Indonesia, 6(1), 122-145.

Maridi, M. (2015). Mengangkat Budaya dan Kearifan Lokal dalam Sistem 
Konservasi Tanah dan Air. In Proceeding Biology Education Conference: Biology, Science, Enviromental, and Learning (Vol. 12, pp. 20-39).

Noor, I. (2016). Identitas Agama, Ruang Publik Dan Post-Sekularisme: Perspektif Diskursus Jurgen Habermas. Jurnal Ilmiah Ilmu Ushuluddin, 11(1), 61-87.

Norsidi, N. (2019). Strategi Pengembangan Pengelolaan Hutan Adat Berbasis Kearifan Lokal Di Desa Lubuk Beringin. Sosial Horizon: Jurnal Pendidikan Sosial, 6(1), 38-52.

Nuris, A. (2016). Tindakan Komunikatif: Sekilas Tentang Pemikiran Jurgen Habermas. Al-Balagh, l(1), 39-66.

Popkin, S. L. (1986). Petani Rasional. Jakarta: Yayasan Padamu Negeri.

Putra, A. W. S., \& Hariadi, S. S. (2016). Peran Kejreun Blang terhadap Perilaku Petani dalam Pengelolaan Air Pertanian di Nanggroe Aceh Darussalam.

Ruhimat, I. S. (2015). Tingkat Motivasi Petani Dalam Penerapan Sistem Agroforestry. Penelitian Sosial Ekonomi Kehutanan, 13(2).

Sudalmi, E. S., \& Hardiatmi, J. M. S. (2018). Usaha Pelestarian Lingkungan Hidup Melalui Penganekaragaman Tanaman Pekarangan (Di Desa Wonorejo, Kecamatan Gondangrejo Kabupaten Karanganyar). Adi Widya: Jurnal Pengabdian Masyarakat, 2(2), 184-189.

Sufia, R., Sumarmi, S., \& Amirudin, A. (2016). Kearifan lokal dalam melestarikan lingkungan hidup (studi kasus masyarakat adat Desa Kemiren Kecamatan Glagah Kabupaten Banyuwangi). Jurnal Pendidikan: Teori, Penelitian, Dan Pengembangan, 1(4), 726-731.

Surtani, S. (2016). Peran Serta Masyarakat dalam Pemanfaatan Sumber Daya Alam Secara Efektif dan Efisien.

Suyatman, U. (2018). Teologi Lingkungan dalam Kearifan Lokal Masyarakat Sunda. Al-Tsaqafa: Jurnal Ilmiah Peradaban Islam, 15(1), 77-88.

Wibowo, H. A., Wasino, W., \& Setyowati, D. L. (2012). Kearifan lokal dalam menjaga lingkungan hidup (Studi kasus masyarakat di Desa Colo Kecamatan Dawe Kabupaten Kudus). Journal of Educational Social Studies, 1(1).

Yew, V. W. C., Ramlan, S. F. M., \& Ahmad, M. R. (2019). Pendekatan kualitatif untuk memahami kualiti hidup masyarakat orang asli di Pahang (Qualitative approach to understanding the quality of life of an indigenous community in Pahang). Geografia-Malaysian Journal of Society and Space, 15(4). 